http://journal.uinsgd.ac.id/index.php/biodjati

\title{
MICROPLASTICS IN PELAGIC AND DEMERSAL FISHES OF PANTAI BARON, YOGYAKARTA, INDONESIA
}

\author{
Nurul Suwartiningsih ${ }^{1 *}$, Indri Setyowati ${ }^{2}$, Resa Astuti ${ }^{3}$
}

Received : February 20, 2020

Accepted : April 17, 2020

DOI: 10.15575/biodjati.v5i1.7768

${ }_{1,2,3}$ Department of Biology, Faculty of Applied Science and Technology

Universitas Ahmad Dahlan,

Yogyakarta 55166

e-mail:

*1nurul.suwartiningsih@bio.uad.ac.id

²indrisetyowati995@gmail.com

resaastuti123@gmail.com

*Corresponding author

Abstract. Yogyakarta is the second-largest producer of plastic waste in Indonesia. Plastic waste in the waters can be degraded into microplastics that can enter the body of a fish. This study aimed to determine the presence of microplastics in the digestive tract of several species of fish in Pantai Baron, Yogyakarta, Indonesia. This research was an exploratory research conducted in April-September 2019 at Pantai Baron, Yogyakarta. Two species of each pelagic and demersal fish samples were taken by buying fish caught by fishermen. The digestive tract of fish was extracted with $10 \% \mathrm{KOH}$, filtered, then visual identification. Microplastic types were estimated by FT-IR spectrometry. The amount of microplastic of all fishes was done by Kruskal-Wallis test while the number of microplastics of the two categories of fish was compared with the Mann-Whitney test. A correlation analysis was carried out between the length of the fish, the weight of the digestive tract and the number of microplastics found. Microplastic shape, color, size, and type data were analyzed descriptively. A total of 78 of the $80(97.50 \%)$ fish from four species studied contained microplastics with a total number as many as 3,651 (mean 45.60 $\pm 44.31 \mathrm{mi-}$ croplastic/individual). About 100\% of pelagic fish samples contained microplastics, while only 95\% of demersal fish samples contained microplastics. Mann-Whitney test results showed the number of microplastic/individual was significantly different between pelagic and demersal fish $(p<0.05)$. The most dominant shape of microplastic was fiber (53.14\%), film (36.97\%) and fragments $(9.89 \%)$. The type of polymers detected was polyamide. The results showed that pelagic fish swallowed more microplastics than demersal fish did because of the microplastic nature that is lightweight and floats. Microplastic characteristic data can be used to estimate the main source of microplastic pollution in Pantai Baron so it can be managed appropriately.

Keywords: digestive tract, fish, microplastic, Pantai Baron, polymer

\section{Citation}

Suwartiningsih, N., Setyowati, I. \& Astuti, R. (2020). Microplastics in Pelagic and Demersal Fishes of Pantai Baron, Yogyakarta, Indonesia. Jurnal Biodjati, 5(1), 33-49.

\section{INTRODUCTION}

Plastics have become a major problem in a water environment because of their persistence (Lebreton et al., 2017). Plastic waste in the waters will be carried by currents and degraded into microparticles (Andrady, 2011) called microplastics. Microplastics are plastic flakes measuring $0.1-5,000 \mu \mathrm{m}$ (EFSA, 2016). Microplastics can enter the body of 


\section{Jurnal Biodjati 5(1):33-49, May 2020 \\ JURNAL BIDDJATI}

http://journal.uinsgd.ac.id/index.php/biodjati

aquatic biota due to the ingestion of water containing microplastics or eating prey that has swallowed microplastics before (Lusher et al., 2017). There have been prior microplastic studies, including that by Rochman et al. (2015), who found that $28 \%$ of fish in the Indonesian Paotere Fish Market contained microplastics in their digestive tracts. Dewi et al. (2015) found three forms of microplastics namely fragments, film and fiber in the sediments in Muara Badak, Kutai Kartanegara. Widianarko \& Hantoro (2018) reported the presence of microplastics in seafood from the North Coast of Java. Hiwari et al. (2019) also found three forms of microplastics: fragments, film and fiber in the seawater around Kupang and Rote, East Nusa Tenggara. Hastuti et al. (2019) reported the presence of microplastics in commercial fishes of Pantai Indah Kapuk, Jakarta, Indonesia. Microplastics are also reported to have been found in honey, beer and salt (EFSA, 2016).

Yogyakarta is the second largest contributor to plastic waste in Indonesia after Makassar. About $39.3 \%$ of the waste generated by residents of the city of Yogyakarta is plastic waste (Cadman et al., 2018). Therefore, it is likely that five major rivers in Yogyakarta carry plastic waste from densely populated areas to the sea in the south of Yogyakarta. One of the seas in the south of Yogyakarta is the sea in the Pantai Baron (Baron Coast) area of Gunungkidul Regency.

Pantai Baron is the landing site of $17 \%$ of fishermen in Gunungkidul (Nahib \& Sutrisno 2010) and has a Fish Auction Place (TPI) (Sarwanto et al., 2014) with the highest number of retailers. Some species of fish that have high economic value commodities in Pantai Baron are Skipjack tuna (Katsuwonus pelamis L.), Frigate tuna (Auxis thazard), Japanese threadfin bream (Nemipterus japonicus) and Large-scale croaker (Johnius heterolepis B.).
Skipjack tuna and Frigate tuna are fish that live on the upper surface to the middle of the waters so that they are categorized as pelagic fish, while Japanese threadfin bream and Large-scale croaker are fish that live on the bottom of the water so they are categorized as demersal fish. Research on microplastics in fishes of Pantai Baron, Yogyakarta has never been done.

It is necessary to conduct research on the analysis of the presence of microplastics in several species of fish in Pantai Baron of Gunungkidul, Yogyakarta, specifically for pelagic and demersal fishes, so the estimation of microplastics distribution at different depths is known. Data on the number and form of microplastics were obtained as information on the presence of novel contaminants in fish that have an impact on food safety. Moreover, important microplastic polymer type data were obtained as information on the possible types of polymers that are the main source of pollutants.

\section{MATERIALS AND METHODS}

This research was an exploratory research conducted in April-September 2019 at Pantai Baron, Gunungkidul Regency, Special Region of Yogyakarta. Two species of pelagic fish (Skipjack tuna and Frigate tuna) and two species of demersal fish (Japanese threadfin bream and Large-scale croaker) samples were taken by buying fish caught by fishermen on Pantai Baron. The fishing area of the fishermen is around $4.5 \mathrm{~km}$ from the shoreline (Figure 1). Of the four species, 120 individuals were taken as samples. A total of 30 individuals for each species were taken as samples with of the following details: 20 individuals to determine the amount, shape, color and size of microplastics data, while 10 were used to estimate the type of microplastics 


\section{JURNAL BIDDJATI}

http://journal.uinsgd.ac.id/index.php/biodjati

polymer. The fish were then put into ice flasks filled with ice cubes to prevent tissue damage when transporting them to the laboratory as the research samples. Prior to microplastics isolation, all equipment to be used was sterilized using aquabidest and 70\% ethanol. The equipment was then wrapped using aluminum foil and dried in an oven at $50^{\circ} \mathrm{C}$ for 12 hours. The sterilization was carried out to prevent contamination in research equipment.

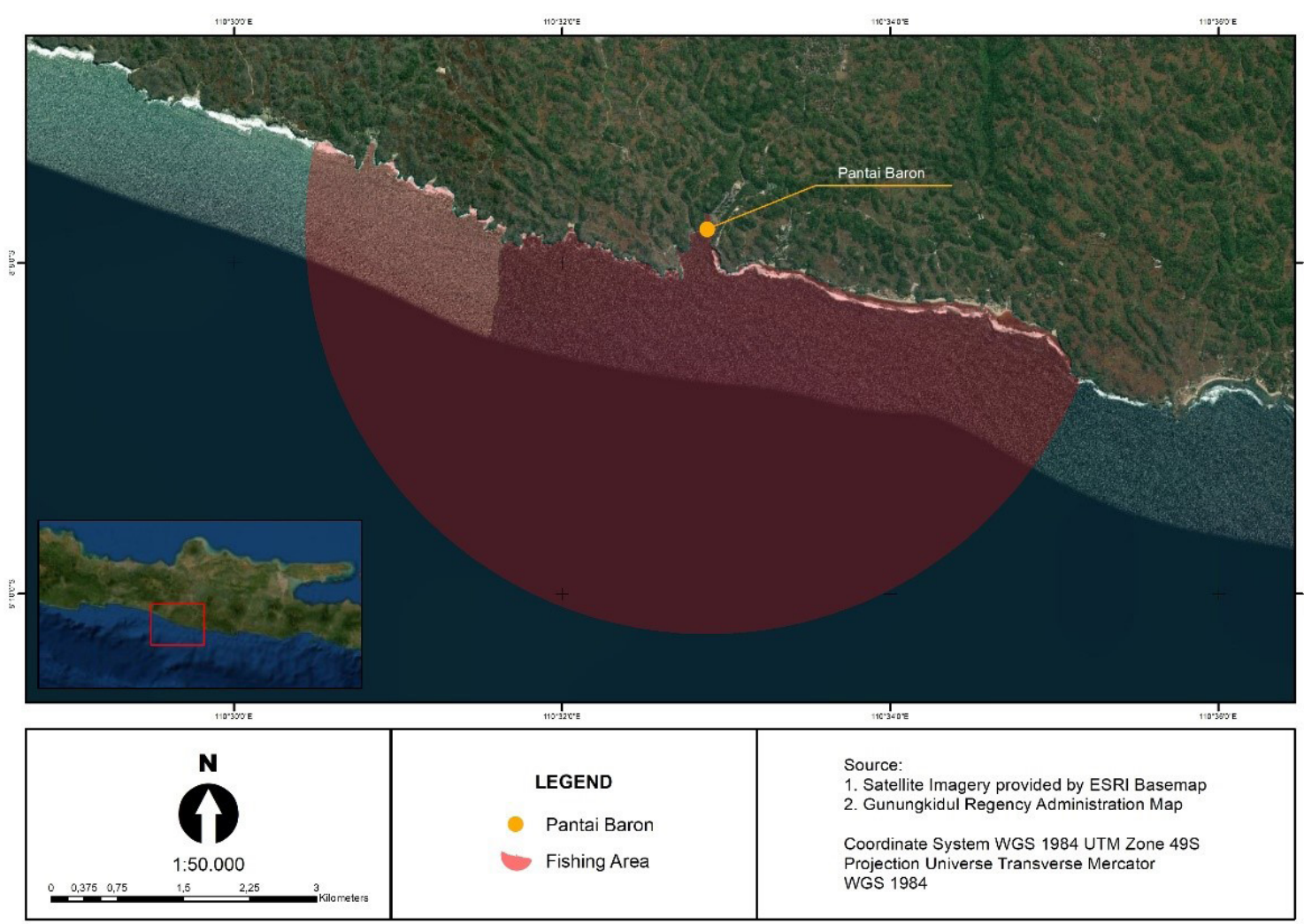

Figure 1. Location of Pantai Baron, Yogyakarta, Indonesia and the fishing area

Microplastics isolation procedure carried out by referring to the protocol written by Rochman et al. (2015). The fish was dissected and the digestive tract was taken from the base of the esophagus to the anus. The digestive tract of fish was then put into a flacon bottle and added with $10 \% \mathrm{KOH}$ as much as \pm 3 times the volume of the digestive tract. The flacon bottle containing the digestive tract and $10 \% \mathrm{KOH}$ was then put into the oven at $60^{\circ} \mathrm{C}$ for 12 hours. An addition of $10 \% \mathrm{KOH}$ solution and heating was conducted to destroy the digestive tract. When heating, a flacon bottle containing only $10 \% \mathrm{KOH}$ solution was put into the oven as a control. The results of deJurnal Biodjati 5(1):33-49, May 2020 struction were then filtered using filter paper to obtain pellets and supernatants. The pellets on the filter paper were then transferred to a petri dish.

The pellets in the petri dish were transferred to glass objects, dropped with distilled water and covered with a cover glass. The pellet was then observed under a light microscope. The maximum magnification used was $10 \mathrm{x} 100$. The observed microplastics were counted using a hand counter and documented using a microscope camera. The Microplastics size was determined using Image Raster software. Microplastic polymer types were estimated by FT-IR spectrometry. 


\section{Jurnal Biodjati 5(1):33-49, May 2020 \\ JURNAL BIODJATI}

http://journal.uinsgd.ac.id/index.php/biodjati

The homogeneity number of microplastics data was tested using the Levene test to determine whether to be tested parametrically or nonparametrically. The Kruskal-Wallis test was used to compare the average number of microplastics found in the digestive tracts of all fishes. Mann-Whitney test was used to compare the average number of microplastics found in the digestive tracts of both categories of fish (pelagic and demersal). In addition, a correlation analysis was carried out to analyze the data between the length of the fish, the weight of the digestive tract of the fish, and the number of microplastics found. Microplastic shape, color, size and type data were analyzed descriptively.

\section{RESULTS AND DISCUSSION}

\section{The Existence of Microplastics}

A total of 78 of the $80(97.50 \%)$ fish studied contained microplastics with a total number of microplastics found as many as 3,651 (mean $45.60 \pm 44.31$ microplastics per individual). A total of $100 \%$ of Skipjack fish and Frigate tuna contained microplastics while $95 \%$ of Japanese threadfin bream and Large-scale croaker contained microplastics. Frigate tuna had the highest range of microplastics per individual (35-215 microplastics per individual), whereas Large-scale croaker had the lowest range of microplastic per individual (0-18 microplastic per individual). The highest number of microplastics per fish was found in Frigate tuna ( $95.65 \pm 38.80 \mathrm{mi}$ croplastics per individual) and the lowest one was found in Large-scale croaker (7.35 \pm 4.48 microplastics per individual) (Table 1).

Table 1. Number of microplastics in the digestive tract of four fish species at Pantai Baron

\begin{tabular}{|c|c|c|c|c|c|c|}
\hline $\begin{array}{c}\text { Local name (Scientific } \\
\text { name) }\end{array}$ & $\begin{array}{l}\text { Number of } \\
\text { samples }\end{array}$ & $\begin{array}{l}\text { Number of } \\
\text { samples with } \\
\text { micropastics }\end{array}$ & $\begin{array}{l}\text { Body } \\
\text { length } \\
(\mathrm{cm})\end{array}$ & $\begin{array}{c}\text { Diges- } \\
\text { tive tract } \\
\text { weight }(\mathrm{g})\end{array}$ & $\begin{array}{l}\text { Range of } \\
\text { microplas- } \\
\text { tics per } \\
\text { individual }\end{array}$ & $\begin{array}{l}\text { Number of } \\
\text { microplas- } \\
\text { tics per } \\
\text { individual } \\
\text { (mean } \pm \\
\text { SD) }\end{array}$ \\
\hline $\begin{array}{l}\text { Skipjack tuna } \\
\text { (Katsuwonus pelamis L.) }\end{array}$ & 20 & 20 & $\begin{array}{c}24.87 \pm \\
1.17\end{array}$ & $\begin{array}{l}13.82 \pm \\
5.76\end{array}$ & $8-46$ & $\begin{array}{c}21.90 \pm \\
11.94\end{array}$ \\
\hline $\begin{array}{l}\text { Frigate tuna } \\
\text { (Auxis thazard) }\end{array}$ & 20 & 20 & $\begin{array}{c}24.33 \pm \\
3.11\end{array}$ & $\begin{array}{c}5.47 \pm \\
2.37\end{array}$ & $35-215$ & $\begin{array}{l}95.65 \pm \\
38.80\end{array}$ \\
\hline $\begin{array}{l}\text { Japanese threadfin bream } \\
\text { (Nemipterus japonicus) }\end{array}$ & 20 & 19 & $\begin{array}{c}24.95 \pm \\
2.54\end{array}$ & $\begin{array}{c}5.81 \pm \\
3.17\end{array}$ & $0-158$ & $\begin{array}{c}57.50 \pm \\
37.61\end{array}$ \\
\hline $\begin{array}{l}\text { Large-scale croaker } \\
\text { (Johnius heterolepis B.) }\end{array}$ & 20 & 19 & $\begin{array}{c}18.71 \pm \\
0.97\end{array}$ & $\begin{array}{c}2.60 \pm \\
0.90\end{array}$ & $0-18$ & $7.35 \pm 4.48$ \\
\hline
\end{tabular}




\section{Jurnal Biodjati 5(1):33-49, May 2020 \\ JURNAL BI@DIATI}

http://journal.uinsgd.ac.id/index.php/biodjati

The Kruskal-Wallis test results showed that the number of microplastics per individual was significantly different between species of fish ( $\mathrm{p}<0.05)$. Mann-Whitney test results showed the number of microplastics per individual was significantly different between pelagic and demersal fish $(\mathrm{p}<0.05)$. The results of the Spearman's rho correlation test showed that the correlation between the length of the fish and the weight of the digestive tract was relatively weak (0.289), while the correlation between the length of the fish and the num- ber of microplastics was moderate (0.539). Spearman's rho correlation coefficient value between the weight of the digestive tract with the number of microplastics was also relatively weak (0.353). The fish length was positively correlated with the weight of the digestive tract and the number of microplastic with a significance value $<0.01$ (Table 2). This means that the longer the body of the fish, the higher the weight of the digestive tract and the higher the number of microplastics found.

Table 2. Correlation between body length, digestive tract weights and the number of microplastics found in the digestive tract of four fish species at Pantai Baron

\begin{tabular}{lllll}
\hline & & Body length & $\begin{array}{c}\text { Digestive tract } \\
\text { weight }\end{array}$ & $\begin{array}{c}\text { Number of } \\
\text { microplastics }\end{array}$ \\
\hline \multirow{3}{*}{ Body length } & Correlation Coefficient & 1.000 & $.289^{* *}$ & $.539^{* *}$ \\
& Sig. (2-tailed) &. & .009 & .000 \\
& $\mathrm{~N}$ & 80 & 80 & 80 \\
& Correlation Coefficient & $.289^{* *}$ & 1.000 & $.353^{* *}$ \\
Digestive tract weight & Sig. (2-tailed) & .009 &. & .001 \\
& $\mathrm{~N}$ & 80 & 80 & 80 \\
& Correlation Coefficient & $.539^{* *}$ & $.353^{* *}$ & 1.000 \\
\multirow{2}{*}{ Number of microplastics } & Sig. (2-tailed) & .000 & .001 &. \\
& $\mathrm{~N}$ & 80 & 80 & 80 \\
**. Correlation is significant at the 0.01 level(2-tailed). & &
\end{tabular}

The research of microplastic in fish has increased in recent years. The results of this study showed the highest percentage of fish containing microplastics $(97.50 \%)$ compared to previous studies, with the highest average microplastic found $45.60 \pm 44.31$ (Table 3 ).

The highest number of microplastics found in this study could be caused by the large amount of plastic waste in Yogyakarta. Yogyakarta is the second largest contributor to plastic waste in Indonesia after Makassar. About $39.3 \%$ of the waste generated by residents of the city of Yogyakarta is plastic waste (Cadman et al., 2018). Indonesia itself is a country ranked second after China in terms of plastic waste that is not managed properly. Every year, Indonesia produces 3.22 million metric tons of plastic waste that is not managed properly, where $0.48-1.29$ million metric tons of plastic waste become pollutants in the sea (Jambeck et al., 2015). However, this comparison also becomes difficult to achieve due to differences in sampling locations, methods and the number of fish species.

The percentage of fish containing microplastics in pelagic fish (Skipjack tuna and Frigate tuna) was higher (100\%) compared to demersal fish (Japanese threadfin bream and 


\section{Jurnal Biodjati 5(1):33-49, May 2020 \\ JURNAL BI@DIATI}

http://journal.uinsgd.ac.id/index.php/biodjati

Large-scale croaker) (95\%). The number of microplastics per individual found between pelagic and demersal fish was also significantly different. Pelagic fish are fish that live on the surface to the middle layer of water (Susilo, 2010), while demersal fish live at the bottom of the waters (Wahyuni et al., 2009). On the surface of the waters, there are many microplastics because of their low density that makes them float on the surface of the waters for a long period of time (Hidalgo-Ruz et al., 2012). Habitats that contain a lot of microplastics will increase the chance of a lot of microplastics being ingested (Wright et al., 2013; Güven et al., 2017).
Microplastics were significantly more common in pelagic fish than demersal fish (Rummel et al., 2016; Güven et al., 2017), although some have stated that they were not significant (Lusher et al., 2013). Another study has shown that more microplastics were found in demersal fish than pelagic fish (Jabeen et al., 2017). Positive correlations between fish length, digestive tract weight and microplastic count were also found in Flathead grey mullet (Mugil cephalus), although the presence of microplastics in the digestive tract was not a permanent phenomenon (Cheung et al., 2018).

Table 3. Microplastic comparison between this study and the previous studies

\begin{tabular}{|c|c|c|c|c|c|c|}
\hline Location & Habitat & $\begin{array}{l}\text { Sample with } \\
\text { micrplastic } \\
\text { (individual) }\end{array}$ & $\begin{array}{l}\text { Percentage of } \\
\text { microplastic } \\
\text { ingestion }(\%)\end{array}$ & $\begin{array}{c}\text { Average of } \\
\text { microplastic } \\
\text { per individual }\end{array}$ & $\begin{array}{l}\text { Extraction } \\
\text { method }\end{array}$ & Reference \\
\hline $\begin{array}{l}\text { Sulawesi, } \\
\text { Indonesia, } \\
\text { California } \\
\text { USA }\end{array}$ & Marine & $\begin{array}{l}21 \text { (INA) } \\
16 \text { (USA) }\end{array}$ & $\begin{array}{l}28 \text { (INA) } \\
25 \text { (USA) }\end{array}$ & $\begin{array}{l}1.40 \pm 3.70 \\
0.50 \pm 1.40\end{array}$ & $10 \% \mathrm{KOH}$ & $\begin{array}{l}\text { Rochman et al. } \\
\text { (2015) }\end{array}$ \\
\hline North Atlantic & Marine & 84 & 11 & $1.20 \pm 0.54$ & $10 \% \mathrm{KOH}$ & $\begin{array}{l}\text { Lusher et al. } \\
(2016)\end{array}$ \\
\hline $\begin{array}{l}\text { Mediterranean } \\
\text { Sea }\end{array}$ & Marine & 771 & 58 & $2.36 \pm 1.36$ & $35 \% \mathrm{H}_{2} \mathrm{O}_{2}$ & $\begin{array}{l}\text { Güven et al. } \\
(2017)\end{array}$ \\
\hline $\begin{array}{l}\text { Mondego, } \\
\text { Portugal }\end{array}$ & Estuary & 46 & 38 & $1.67 \pm 0.27$ & $10 \% \mathrm{KOH}$ & $\begin{array}{l}\text { Bessa et al. } \\
(2018)\end{array}$ \\
\hline $\begin{array}{l}\text { Jakarta } \\
\text { Indonesia }\end{array}$ & Marine & 169 & 97.13 & $12.21 \pm 9.76$ & $\mathrm{NaCl}$ & $\begin{array}{l}\text { Hastuti et al. } \\
(2019)\end{array}$ \\
\hline $\begin{array}{l}\text { Pantai Baron, } \\
\text { Indonesia }\end{array}$ & Marine & 78 & 97.50 & $45.60 \pm 44.31$ & $10 \% \mathrm{KOH}$ & This study \\
\hline
\end{tabular}

\section{Microplastic Shape}

The most dominant shape of microplastic in the four fish species was fiber 53.14\% (1,940 of 3,651 microplastic), followed by film $36.97 \%$ (1,350 of 3,651 microplastic) and fragments $9.89 \%$ (361 of 3,651 microplastic). The most dominant shape of microplastic in Skipjack tuna and Frigate tuna was fiber $(46.80 \%$ and $65.87 \%)$. The most dominant microplastic in Japanese threadfin bream was film (65.22\%). The most dominant microplastic in Large-scale croaker was fragment $(71.43 \%)$, while no film-shaped microplastic was found (Figure 2). The most dominant shape of microplastic in pelagic fish was fiber $(62.31 \%)$, whereas in demersal fish the most dominant shape of microplastic was film $(57.85 \%)$ (Figure 3$)$. 


\section{Jurnal Biodjati 5(1):33-49, May 2020 \\ JURNAL BI@DJATI}

http://journal.uinsgd.ac.id/index.php/biodjati

$120 \%$

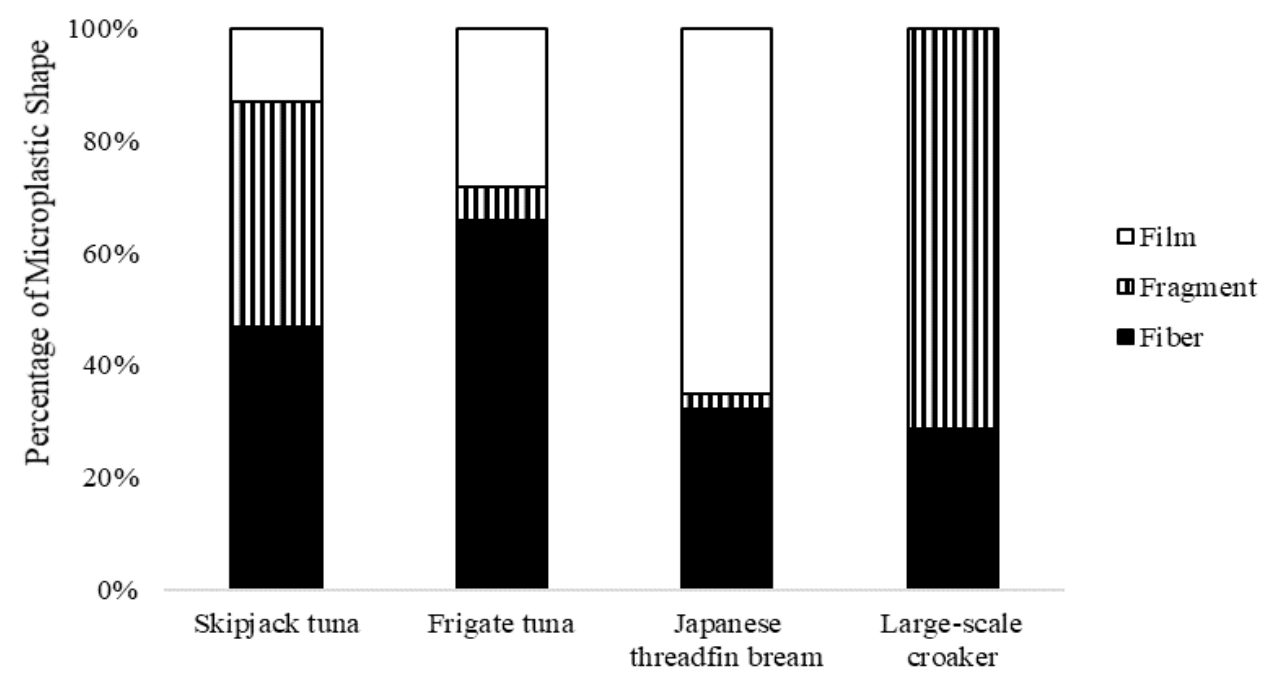

Figure 2. Microplastic shape in the digestive tract of four fish species at Pantai Baron
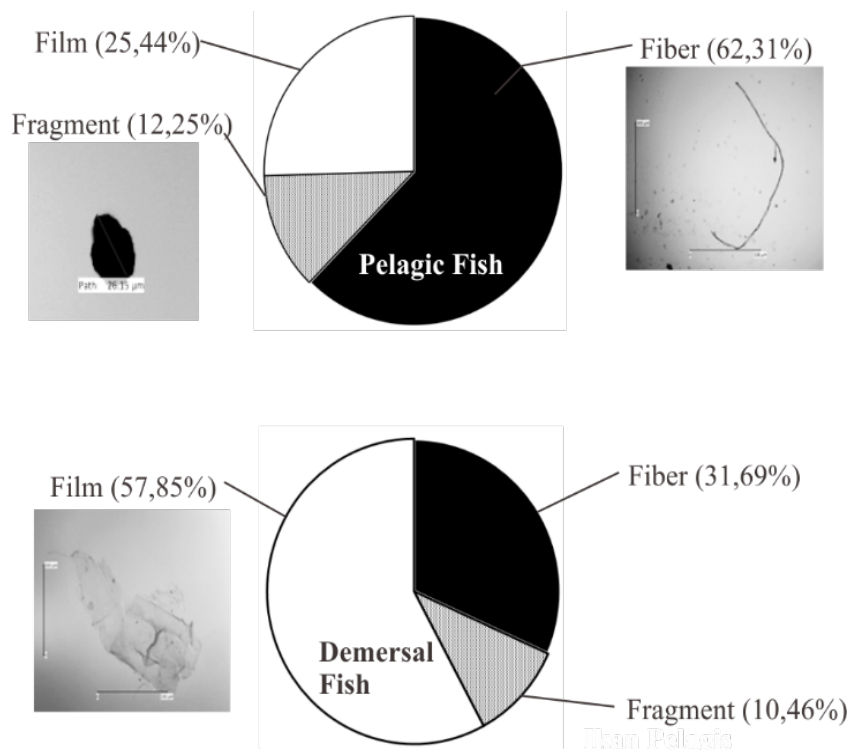

Figure 3. Comparison of microplastic shape in pelagic and demersal fish

Previous research also found that the most dominant microplastics were fiber (Lusher et al., 2013; Rummel et al., 2016; Güven et al., 2017; Vendel et al., 2017; Bessa et al., 2018; Cheung et al., 2018; Hastuti et al., 2019), followed by films (Vendel et al., 2017) and fragments (Vendel et al., 2017). Fiber is an elongated plastic fiber, derived from syn- thetic fabric flakes, nets or ropes (Dewi et al., 2015). Fiber can come from fishing rods, fishing nets (Dewi et al., 2015) or washing activities (Rohman et al., 2015; Hiwari et al., 2019). Films are the fragments with the lowest density (Dewi et al., 2015), derived from plastic bags and food packaging (Hiwari et al., 2019). Fragments are plastic flakes with strong syn- 


\section{Jurnal Biodjati 5(1):33-49, May 2020 \\ JURNAL BI@DIATI}

http://journal.uinsgd.ac.id/index.php/biodjati

thetic polymers, derived from flakes of pipes, gallons, jars and beverage bottles (Dewi et al., 2015).

The domination of fiber in Skipjack tuna and Frigate tuna could be caused by the fact that it looked similar to food, anchovy and shrimp (Azwir et al., 2004). Films microplastics contained in Japanese thread bream were thought to be similar to food, Bacillariophyceae (Wahyuni et al., 2009). The fragment contained in Large-scale croaker was probably originated from their diet, zoobenthos (Perkins et al., 2019), where benthic organisms accumulated a lot of fragments (Markic et al., 2018).

The shape of microplastic that was found was influenced by food habits (Hastuti et al., 2019). Fiber being found dominant in pelagic fish might be because it had a thin size so that it was found floating on the surface of the water (Hiwari et al., 2019) or because it had a shape similar to their food. Film was found to be dominant in demersal fish possibly because it had the lowest density so that it was easily transported (Dewi et al., 2015) and had a larger size than the fragment (Figure 6). A previous study has also found only fiber and film in demersal fish (Rochman et al., 2015).

\section{Microplastic Color}

The most dominant microplastic color in the four fish species was black $41.06 \%(1,499$ of 3,651 microplastic), followed by brown $26.81 \%$ (979 of 3,651 microplastic), transparent $24.10 \%$ ( 880 of 3,651 microplastic), blue $4.22 \%$ (154 of 3,651 microplastics), red $1.81 \%$ (66 of 3,651 microplastics) and other colors $2.00 \%$ (73 of 3,651 microplastics). The most dominant microplastic color in Skipjack tuna and Frigate was black (39.95\% and 62.99\%). The most dominant microplastic color in Japanese threadfin bream was brown (57.94\%). The most dominant microplastic color in Large-scale croaker was blue (40.14\%) (Figure 4). The most dominant microplastic color in pelagic fish was black $(58.70 \%)$, while in demersal fish the most dominant microplastic color was brown (51.39\%) (Figure 5).

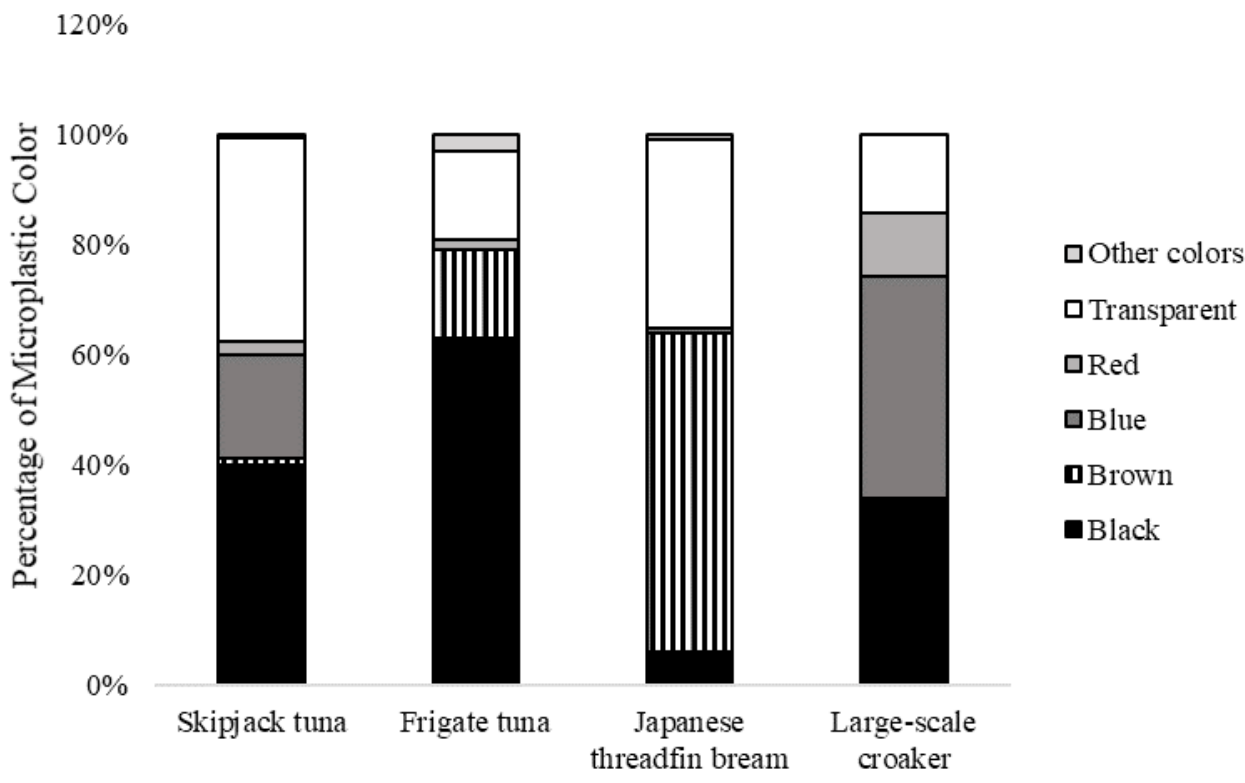

Figure 4. Microplastic color in the digestive tract of four fish species at Pantai Baron 


\section{JURNAL BIDDJATI}

http://journal.uinsgd.ac.id/index.php/biodjati

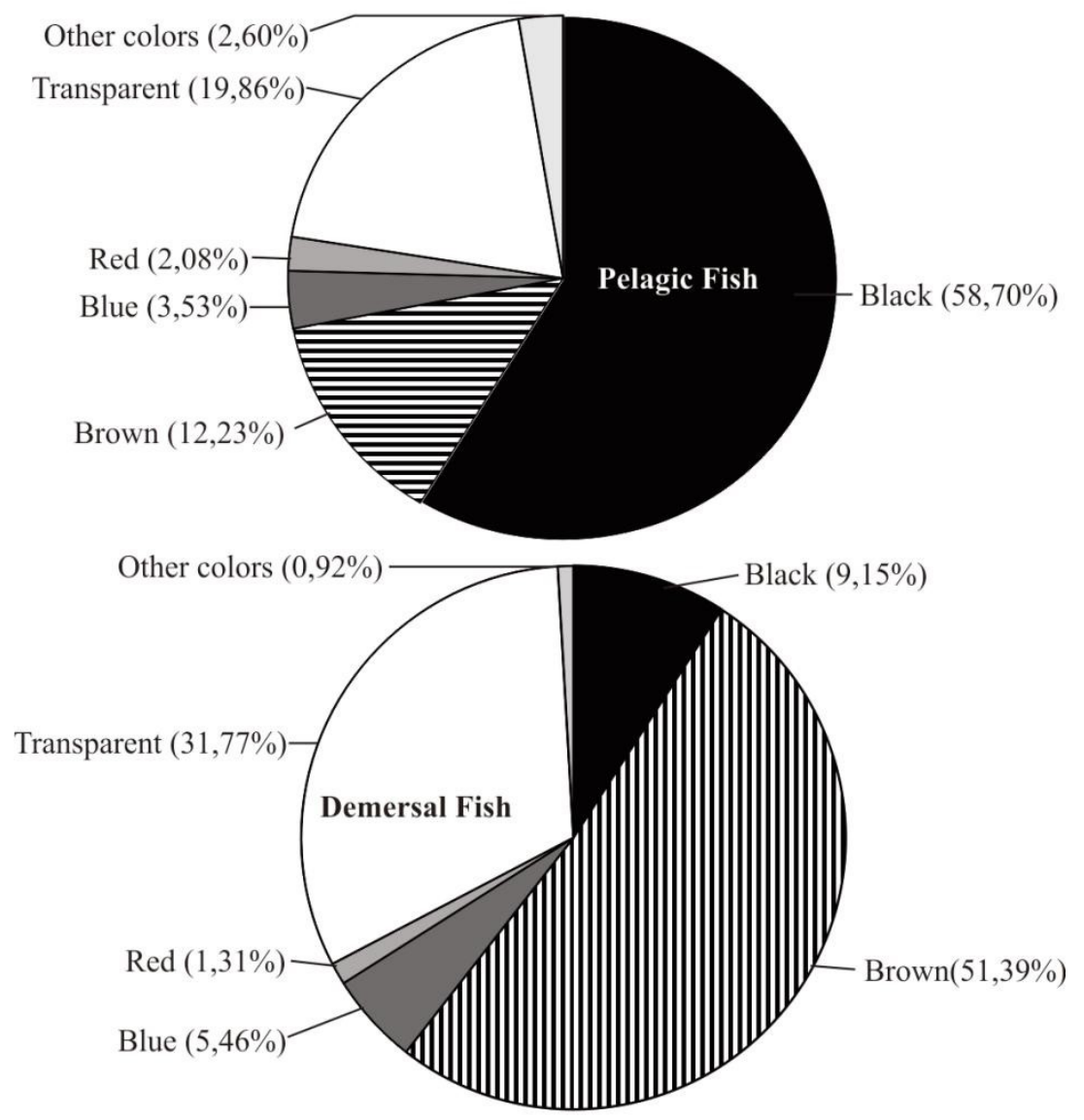

Figure 5. Comparison of microplastic color in pelagic and demersal fish

Microplastic discoloration after the digestion process has never been reported. Research that has been done is the addition of several substances to extract microplastic, such as low concentration $\mathrm{HCl}$ that did not change the morphology (shape and color) of microplastics (Karami et al., 2017), neither does enzymes (Cole et al., 2014). Many fishes have retinal cones in their eyes so they have the ability to detect color (Kardong, 2009), including detecting the food color. Microplastic colors that are similar to natural foods of fish increase the potential for ingestion (Hastuti et al., 2019), due to errors in detecting prey (Ory et al., 2017).

Previous research also found that the most dominant microplastic was black (Lusher et al., 2013; Rummel et al., 2016; Güven et al., Jurnal Biodjati 5(1):33-49, May 2020
2017; Vendel et al., 2017; Bessa et al., 2018; Cheung et al., 2018; Hastuti et al., 2019). Black microplastic is caused by its ability to absorb pollutants (Hiwari et al., 2019). In Skipjack tuna and Frigate tuna, black microplastics were the most dominant. In Japanese thread bream, brown microplastics were the most dominant. The brown color is similar to the color of Polychaeta and Bacillariophyceae as the food (Wahyuni et al., 2009). In Large-scale croaker, blue microplastics were the most dominant. This color may be similar to its natural food, zoobenthos (Perkins et al., 2019).

Pelagic and demersal fish were found to have a dominant black microplastic color, indicating high contaminants absorbed in microplastics (Hiwari et al., 2019) at sea level. The brown color was found dominant in de- 


\section{Jurnal Biodjati 5(1):33-49, May 2020 \\ JURNAL BI@DIATI}

http://journal.uinsgd.ac.id/index.php/biodjati

mersal fish. The brown color found was still concentrated which means it had not been significantly discolored (Hiwari et al., 2019) when ingested by fish at the bottom.

\section{Microplastic Size}

Microplastic sizes found in all four fish species ranged from 9.60 to $599.86 \mu \mathrm{m}$; the most dominant size was 51-100 $\mu \mathrm{m}$ with a percentage of $34.51 \%$. The fiber had a size of 24.42-599.86 $\mu \mathrm{m}$; most were at the size of $51-100 \mu \mathrm{m}(39.84 \%)$. Fragments size ranged from 9.60-222.41 $\mu \mathrm{m}$; most were at the size of $0-50 \mu \mathrm{m}(60.32 \%)$. The films ranged from 24.58 to $420.30 \mu \mathrm{m}$; most were at the size of 51-100 $\mu \mathrm{m}$ (30.19\%). In general, fiber had the longest size. Fragments had a smaller size than film. The number of microplastics found tended to decrease with the increase of microplastic size (Figure 6).

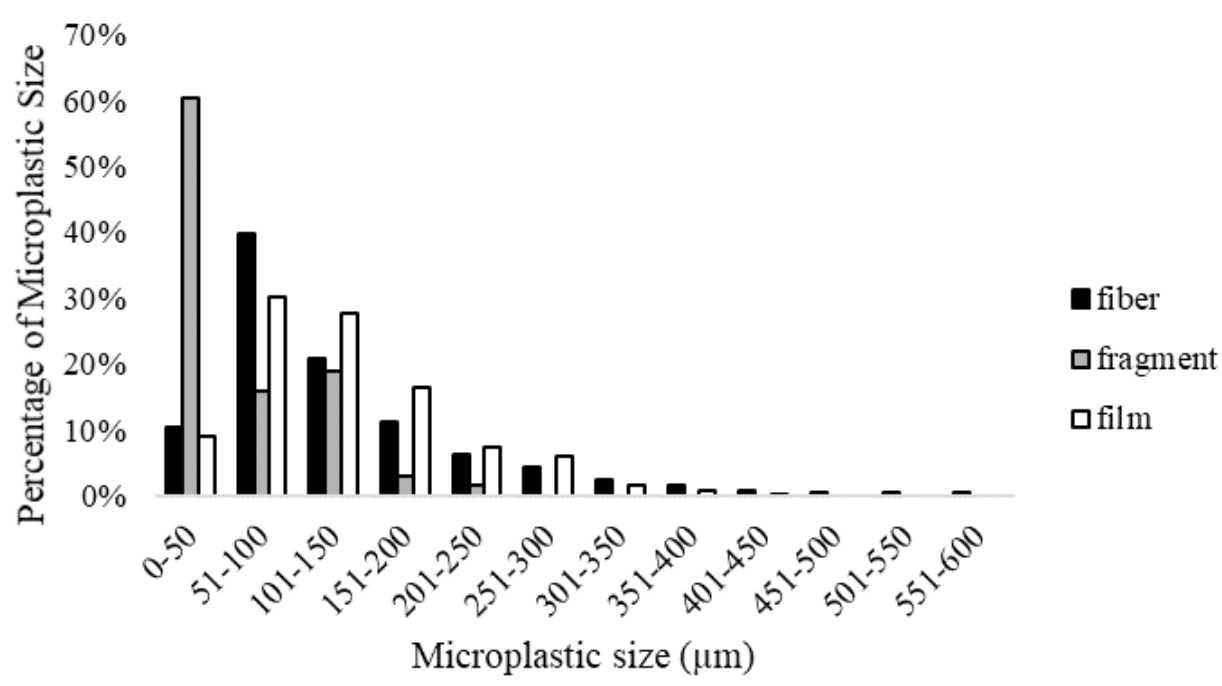

Figure 6. Percentage of microplastic size in the digestive tract of four fish species at Pantai Baron

Microplastics found in pelagic fish ranged from 9.60 to $57.30 \mu \mathrm{m}$; the most dominant size was 51-100 $\mu \mathrm{m}(44.58 \%)$. The fiber had a size of 24.42-576.23 $\mu \mathrm{m}$; most were commonly found in sizes of 51-100 $\mu \mathrm{m}$ (48.87\%). Fragments measured 9.60-222.41 $\mu \mathrm{m}$; most were commonly found in sizes of $0-50 \mu \mathrm{m}(54.76 \%)$. The films ranged from 24.58-359.62 $\mu \mathrm{m}$; most were commonly found in sizes of $51-100 \mu \mathrm{m}(42.75 \%)$ (Figure 7 ).
In demersal fish, microplastic size of 12.26-599.86 $\mu \mathrm{m}$ was found; the most dominant size was $101-150 \mu \mathrm{m}(25.73 \%)$. The fiber had size of $27.50-599.86 \mu \mathrm{m}$; the most common size was $51-100 \mu \mathrm{m}$. The fragments were 12.26-168.87 $\mu \mathrm{m}$; most sizes were $0-50 \mu \mathrm{m}(71.43 \%)$. The films ranged from 24.75 to $420.30 \mu \mathrm{m}$; most were at the size of 101-150 $\mu \mathrm{m}$ (31.84\%) (Figure 8). 


\section{Jurnal Biodjati 5(1):33-49, May 2020 \\ JURNAL BI@DJATI}

http://journal.uinsgd.ac.id/index.php/biodjati

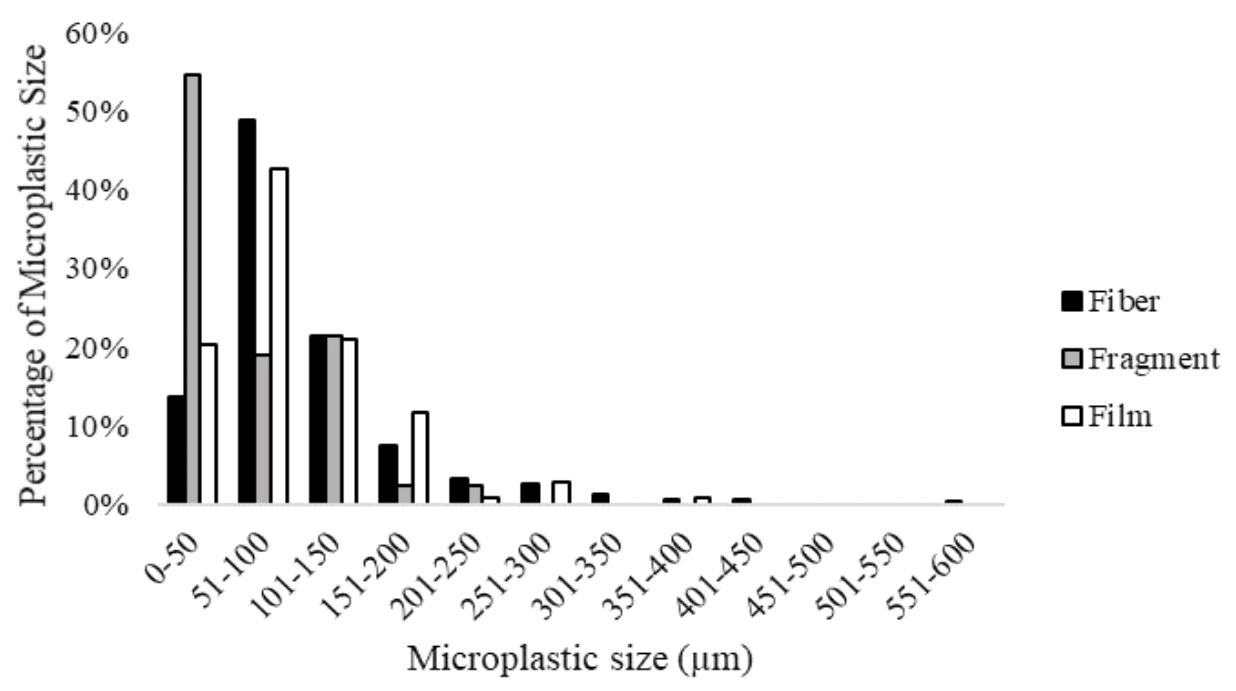

Figure 7. Percentage of microplastic size in the digestive tract of pelagic fish

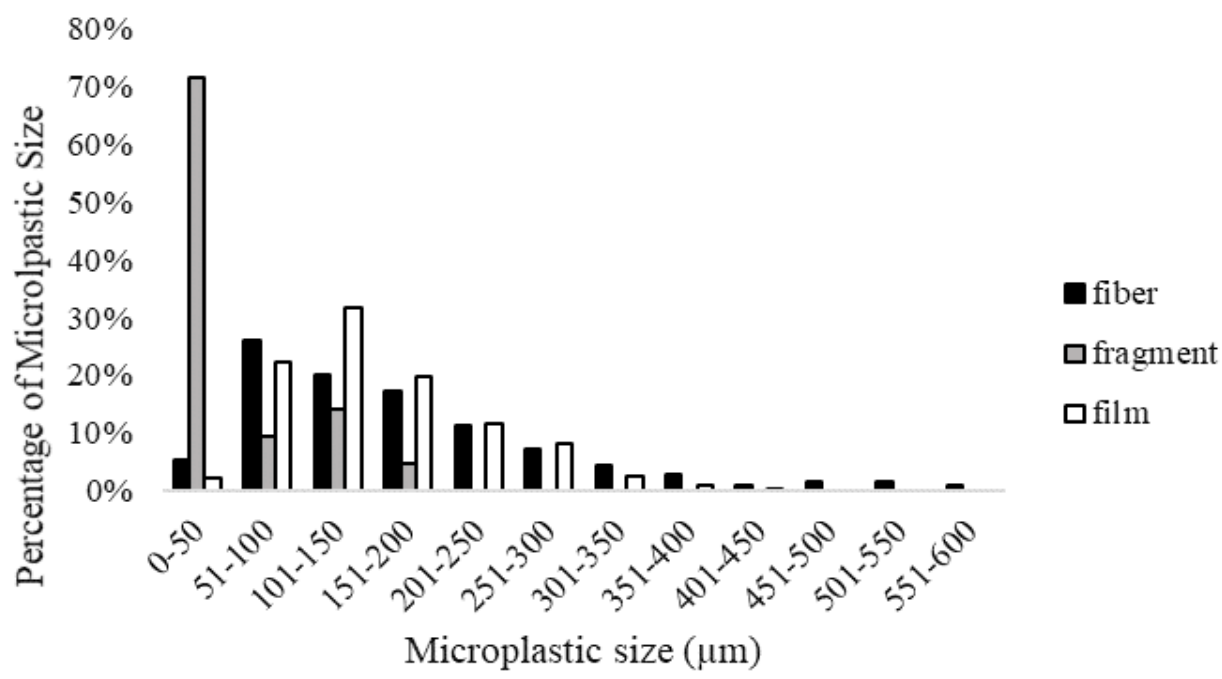

Figure 8. Percentage of microplastic size in the digestive tract of demersal fish

Microplastic size affects the chance of swallowing and its ability to penetrate body tissues (Hastuti et al., 2019). The microplastic size that is large and undigested can stay, abrade and block the intestine (Wright et al., 2013). This can cause malnutrition, hunger and even a decline in fish populations (BoJurnal Biodjati 5(1):33-49, May 2020 erger et al., 2010). The small microplastic size means providing greater surface area for contaminant absorption (Gall \& Thompson, 2015; GESAMP, 2015). The toxic effects of microplastics include death, enzyme biotransformation, stress and oxidative damage (de Sá et al., 2018). 


\section{Jurnal Biodjati 5(1):33-49, May 2020 \\ JURNAL BIDDJATI}

http://journal.uinsgd.ac.id/index.php/biodjati

The microplastic size found in all four species of fish was smaller than that of previous studies. Microplastics with a length of $3.50 \mathrm{~mm}$ and a width of 0.10-4.50 $\mathrm{mm}$ were found in the digestive tract of fish from the Patoere fish market, Indonesia; whereas microplastics with a length of $6.30 \mathrm{~mm}$ and a width of 0.01 to $2.10 \mathrm{~mm}$ were found in the digestive tract of fish from California, USA (Rochman et al., 2015). Microplastics measuring 0.50-11.70 $\mathrm{mm}$ were detected in mesopelagic fish from the North Atlantic, with only $8 \%$ measuring $<1 \mathrm{~mm}$ (Lusher et al., 2016). Microplastics ranged from 9.07-12,074.11 $\mu \mathrm{m}$ were found in the digestive tract of fish from the Mediterranean Sea, Turkey (Güven et al., 2017). Microplastics measuring 0.10$4.90 \mathrm{~mm}$ were found in Flathead grey mullet (Mugil cephalus), with a size dominance of $>2 \mathrm{~mm}$ (Cheung et al., 2018). Microplastic sizes of 100-500 $\mu \mathrm{m}$ were found in commercial marine fish from the South Pacific (Markic et al., 2018). Microplastics with a size of $>149 \mu \mathrm{m}$ were found in commercial marine fish from Malaysia (Karbalaei et al., 2019). Size 100-500 $\mu \mathrm{m}$ microplastics were found in Jakarta Bay sediments, Indonesia; the microplastic size of the water sample was 20-40 $\mu \mathrm{m}$ (Manalu et al., 2017). Size 5-2,000 $\mu \mathrm{m}$ microplastics were found in the water around Kupang and Rote, East Nusa Tenggara, Indonesia; with a predominant size of 5-231 $\mu \mathrm{m}$ (Hiwari et al., 2019).

The fibers, fragments and films found were smaller than those found in fish from Pantai Indah Kapuk, Jakarta, Indonesia, with a size of $<20-5,000 \mu \mathrm{m}$ (fiber), $<100$ $5,000 \mu \mathrm{m}$ (fragments) and $<200-100,000 \mu \mathrm{m}$ (film) (Hastuti et al., 2019). The microplastic size that is small indicates the length of the degradation process experienced (Hiwari et al., 2019). Microplastic degradation can be caused by erosion, temperature or photooxidation (Karbalaei et al., 2019).

Microplastics found in pelagic fish had smaller size dominance than those found in demersal fish. Microplastic with a low density will float on the surface of the water for a long time (Hidalgo-Ruz et al., 2012) so that the opportunity to be swallowed by pelagic fish is higher. Meanwhile, microplastics with a larger size will sink and have the chance to be swallowed by demersal fish.

\section{Microplastic Type}

FTIR results showed the absorption of the N-H stretching group $\left(3,384.63 \mathrm{~cm}^{-1}\right.$; $\left.3,448.72 \mathrm{~cm}^{-1} ; 3,443.10 \mathrm{~cm}^{-1} ; 3,425.58 \mathrm{~cm}^{-1}\right)$, $\mathrm{C}-\mathrm{H}_{2}$ stretching $\left(2,850.93 \mathrm{~cm}^{-1} ; 2931.80 \mathrm{~cm}^{-1}\right.$; $\left.2,924.64 \mathrm{~cm}^{-1} ; 2,924.09 \mathrm{~cm}^{-1}\right), \mathrm{C}=\mathrm{O}$ stretching $\left(1,786.53 \mathrm{~cm}^{-1} ; 1,658.73 \mathrm{~cm}^{-1} ; 1,646.30 \mathrm{~cm}^{-1}\right.$; $\left.1,651.07 \mathrm{~cm}^{-1}\right)$; N-H bending $\left(1,470.41 \mathrm{~cm}^{-1}\right.$; $1,558.48 \mathrm{~cm}^{-1} ; 1,463.67 \mathrm{~cm}^{-1} ; 1,465.90 \mathrm{~cm}^{-1}$ ), C-N bending $\left(1,034.27 \mathrm{~cm}^{-1} ; 1,033.85 \mathrm{~cm}^{-1}\right.$; $\left.1,033.04 \mathrm{~cm}^{-1} ; 1,041.56 \mathrm{~cm}^{-1}\right)$ and $\mathrm{C}-\mathrm{H}$ bending $\left(859.89 \mathrm{~cm}^{-1} ; 871.82 \mathrm{~cm}^{-1} ; 872.29 \mathrm{~cm}^{-1}\right.$; $856.39 \mathrm{~cm}^{-1}$ ) (Figure 9a \& 9b).

Based on FTIR results, it was suspected that the type of microplastic found was polyamide (PA). General polyamide is used as a net material (Ibrahim et al., 2017) so that the presence of this type of microplastic was estimated to be from fishing activities. Previous research also found types of polyimide from the digestive tract of fish (Ibrahim et al., 2017; Bessa et al., 2018).

Microplastics were found in pelagic fish more than demersal fish because of the microplastic nature that is lightweight and floats. More extensive research is needed on sediments, waters, other species of organisms, other species of fish, other organs in fish and toxic effects on mice/ rats. 
Jurnal Biodjati 5(1):33-49, May 2020

\section{JURNAL BI@DJATI}

http://journal.uinsgd.ac.id/index.php/biodjati
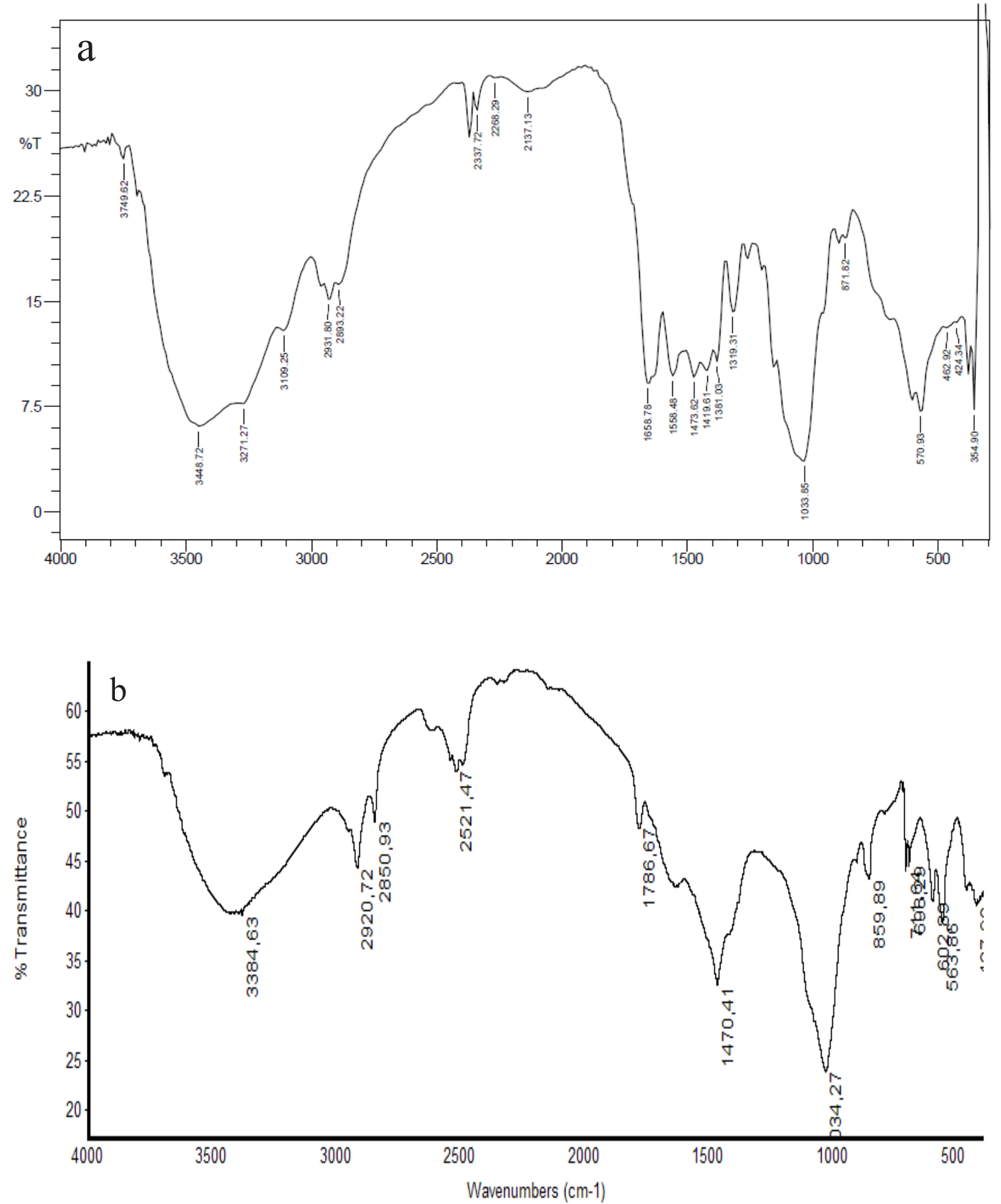

Figure 9a. FTIR Result: a. Skipjack tuna, b. Figate tuna 
Jurnal Biodjati 5(1):33-49, May 2020

\section{JURNAL BI@DJATI}

http://journal.uinsgd.ac.id/index.php/biodjati
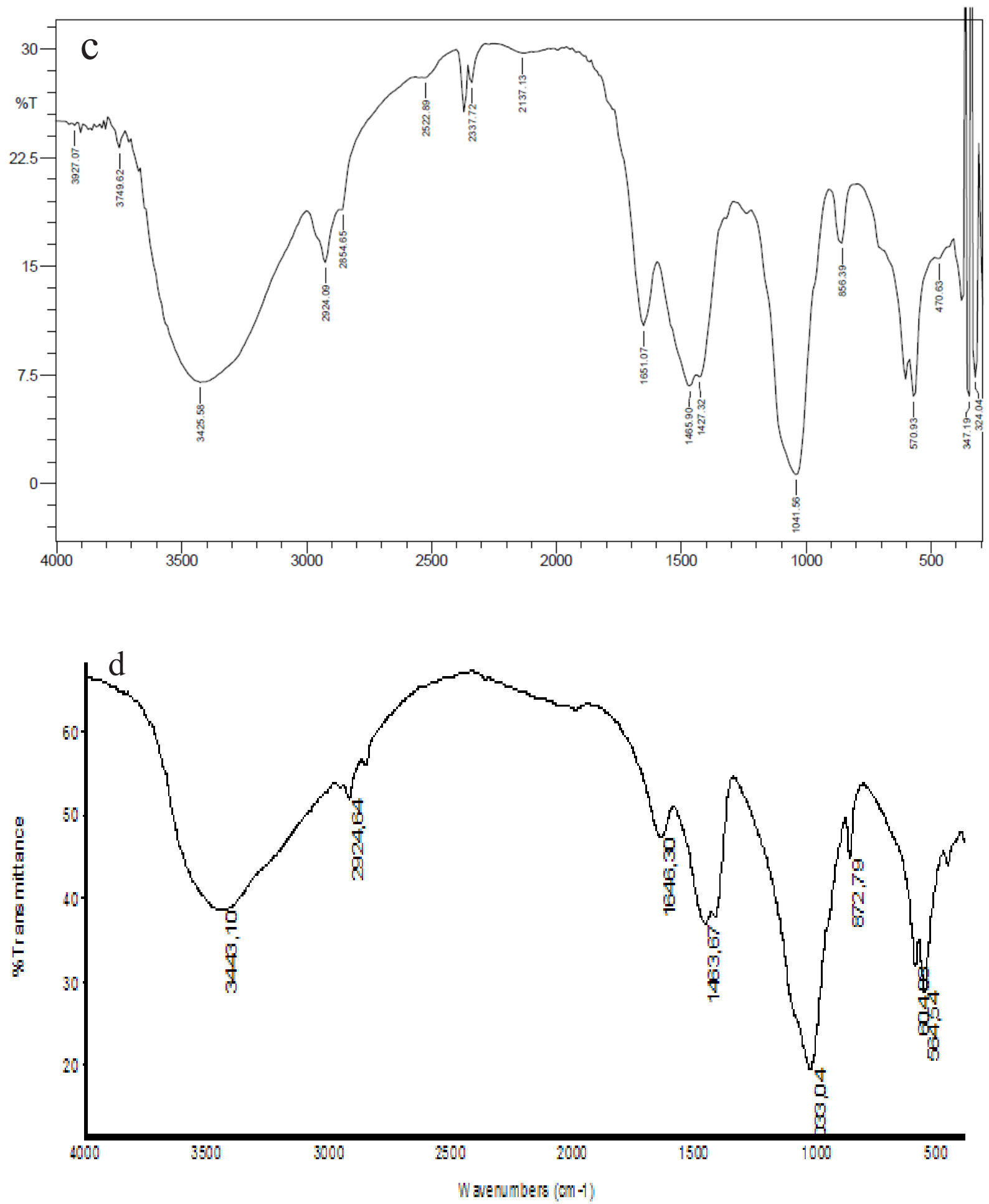

Figure 9b. FTIR Result: c. Japanese threadfin bream, d. Large-scale croaker 


\section{Jurnal Biodjati 5(1):33-49, May 2020 \\ JURNAL BI@DIATI}

http://journal.uinsgd.ac.id/index.php/biodjati

\section{ACKNOWLEDGEMENTS}

We would like to thank Lembaga Penelitian dan Pengabdian kepada Masyarakat (LPPM) Universitas Ahmad Dahlan Yog yakarta for material support with a research contract number PF-109/SP3/LPPM-UAD/ IV/2019.

\section{REFERENCES}

Andrady, A. L. (2011). Microplastics in The Marine Environment. Marine Pollution Bulletin, 62(8), 1596-1605.

Azwir, Muchlisin, Z. A. \& Ramadhani, I. (2004). Studi Isi Lambung Ikan Cakalang (Katsuwonus pelamis) dan Tongkol (Auxis thazard). Jurnal Natural, 4(2), 20-23.

Bessa, F., Barria, P., Neto, J. M., Frias, J. P. G. L., Otero, V., Sobral, P. \& Marques, J. C. (2018). Occurrence of Microplastics in Commercial Fish from a Natural Estuarine Environment. Marine Pollution Bulletin, 128, 575-584.

Boerger, C. M., Lattin, G. L., Moore, S. L. \& Moore, C. J. (2010). Plastic Ingestion by Planktivorous Fishes in the North Pacific Central Gyre. Marine Pollution Bulletin, 60(12), 2275-2278.

Cadman, C. A., Shuker, I., Butler, K., Mitchell, L., Latuheru, J., Asquf, H., Pratomo, I. S. Y., Idrus, R. M., Pangermanan, P., Khirlan, Pratamasari, I., Noor, I., Prasetyawati, A., Sarah M., Utomo, K. P. \& Acharya, A. (2018). Hotspot Sampah Laut Indonesia. Jakarta: Laporan Sintesis WBG.

Cheung, L. T. O., Lui, C. Y. \& Fok, L. (2018). Microplastic Contamination of Wild and Captive Flathead Grey Mullet (Mugil cephalus). Int. J. Environ. Public Health, 15(597), 1-11.
Cole, M., Webb, H., Lindeque, P. K., Fileman, E. S., Halsband, C. \& Galloway, T.S. (2014). Isolation of Microplastics in Biota-Rich Seawater Sample Sand Marine Organisms. Scientific Reports, 4, 4528.

de Sá, L. C., Oliveira, M., Ribeiro, F., Rocha, T. L. \& Futter, M. N. (2018). Studies of the Effects of Microplastics on Aquatic Organism: What do We Know and Where Should We Focus Our Efforts in the Future. Science of the Total Environment, 645, 1029-1039.

Dewi, I. S., Budiarsa, A. A. \& Ritonga, I. R. (2015). Distribusi Mikroplastik pada Sedimen di Muara Badak, Kabupaten Kutai Kartanegara.Depik,4(3), 121-131.

EFSA. (2016). Presence of Microplastics and Nanoplastics in Food, With Particular Focus on Seafood: EFSA Panel on Contaminants in the Food Chain $(\mathrm{CON}$ TAM). EFSA Journal, 14(6), 4501.

Gall, S. C. \& Thompson, R. C. (2015). The Impact of Debris on Marine Life. Marine Pollution Bulletin, 92, 170-179.

GESAMP. (2015). Sources, Fate and Effects of Microplastics in the Marine Environment: A Global Assessment. London: International Maritime Organization.

Güven, O., Gökdağ, K., Jovanović, B. \& Kideyş, A. E. (2017). Microplastic Litter Composition of the Turkish Territorial Waters of the Mediterranean Sea and its Occurrence in the Gastrointestinal Tract of Fish. Environmental Pollution, 223, 286-294.

Hastuti, A. R., Lumbanbatu, D. T. F. \& Wardiatno, Y. (2019). The Present of Microplastics in the Digestive Tract of Commercial Fishes of Pantai Indah Kapuk coast, Jakarta, Indonesia. Biodiversitas, 20(5), 1233-1242.

Hidalgo-Ruz, V., Gutow, L., Thomson, R. C. \& Thiel, M. (2012). Microplastics in the 


\section{Jurnal Biodjati 5(1):33-49, May 2020 \\ JURNAL BI@DIATI}

http://journal.uinsgd.ac.id/index.php/biodjati

Marine Environment: A Review of the Methods Used for Indentification and Quantification. Environmental Science and Technology, 46(6), 3060-3075.

Hiwari, H., Purba, N. P., Ihsan, Y. N., Yuliadi, L. P. S. \& Mulyani, P. G. (2019). Kondisi Sampah Mikroplastik di Permukaan Air Laut Sekitar Kupang dan Rote, Provinsi Nusa Tenggara Timur. Prosiding Seminar Nasional Masyarakat Biodiversitas Indononesia, 5(2), 165-171.

Ibrahim, Y. S., Rathnam, R., Anuar, S. T. \& Khalik, W. M. A. W. M. (2017). Isolation and Characterisation of Microplastic Abudance in Lates Calcarifer from Setiu Wetlands, Malaysia. Malaysian Journal of Analytical Sciences, 21(5), 1054-1064.

Jabeen, K., Su, L., Li, J., Yang, D., Tong, C., Mu, J. \& Shi, H. (2017). Microplastics and Mesoplastics in Fish from Coastal and Fresh Water of China. Environmental Pollution, 221, 141-149.

Jambeck, J. R., Geyer, R., Wilcox, C., Siegler, T. R., Perryman, M., Andrady, A., Narayan, R. \& Law, K. L. (2015). Plastic Waste Inputs from Land into the Ocean. Science, 347(6223), 768-771.

Karami, A., Golieskardi, A., Choo, C. K., Romano, N., Ho, Y. B. \& Salamatinia, B. (2017). A High Performance Protocol for Extraction of Microplastics in Fish. Science of the Total Environment, 578, 485-494.

Karbalaei, S., Golieskardi, A., Hamzah, H. B., Abdulwahid, S., Hanachi, P., Walker, T. R. \& Karami, A. (2019). Abudance and Characteristic of Microplastics in Commercial Marine Fish from Malaysia. Marine Pollution Bulletin, 148, 5-15.

Kardong, K. V. (2009). Vertebrates Comparative Anatomy, Function, Evolution Fifth Edition. New York: McGraw-Hill.
Lebreton, L. C. M., Zwet, J. V. D., Damsteeg, J. W., Slat, B., Andrady, A. \& Reisser, J. (2017). River Plastic Emissions to the World's Oceans. Nature Communications, 8(15611), 1-10.

Lusher, A. L., McHugh, M. \& Thompson, R. C. (2013). Occurrence of Microplastics in the Gastrointestinal Tract of Pelagic and Demersal Fish from the English Channel. Marine Pollution Bulletin, 67(1-2), 94-99.

Lusher, A. L., Donnell, C. O., Officer, R. \& O'Connor, I. (2016). Microplastic Interaction with North Atlantic mesopelagic Fish. ICES Journal of Marine Science, 73(4), 1214-1225.

Lusher, A. L., Welden, N. A., Sobral, P. \& Cole, M. (2017). Sampling, Isolating and Identifying Microplastics Ingested by Fish and Invertebrates. The Royal Society of Chemistry, 9, 1346-1360.

Manalu, A. A., Hariyadi, S. \& Wardiatno, Y. (2017). Microplastics Abudance in Coastal Sendiments of Jakarta Bay, Indonesia. AACL Bioflux, 10(5), 11641173.

Markic, A., Niemand, C., Bridson, J. H., Gaertner, N. M., Gaertner, J. C., Eriksen, M. \& Bowen, M. (2018). Double Trouble in the South Pacific Subtropical Gyre: Increased Plastic Ingestion by Fish in the Oceanic Accumulation Zone. Marine Pollution Bulletin, 136, 547-564.

Nahib, I. \& Sutrisno, D. (2010). Prediksi Pola Sebaran Fishing Ground Nelayan di Perairan Selatan Yogyakarta. Globë, 12(1), $9-20$.

Ory, N. C., Sobral, P., Ferreira, J. L. \& Thiel, M. (2017). Amberstripe Scad Decapterus muroadsi (Carangudae) Fish Ingest Blue Microplastics Resembling Their Copepod Prey Along the Coast of Rapa 


\section{Jurnal Biodjati 5(1):33-49, May 2020 \\ JURNAL BI@DIATI}

http://journal.uinsgd.ac.id/index.php/biodjati

Nui (Easter Island) in the South Pacific Subtropical Gyre. Science of the Total Environment, 586, 430-437.

Perkins, M. J., Mak, Y. K. Y, Law, C. S. W., Tao, L. S. R, Yau, J. K. C. \& Leung, K. M. Y. (2019). Length-Weight Relationships of 79 Marine Fish Species from the Coastal Waters of Hing Kong. Journal of Applied Ichthyology, 35(3), 779-788.

Rochman, C. M., Tahir, A., Williams, S. L., Baxa, D. V., Lam, R., Miller, J. T., Teh, F., Werorilangi, S. \& Teh, S. J. (2015). Anthropogenic Debris in Seafood: Plastic Debris and Fibers from Textiles in Fish and Bivalves Sold for Human Consumption. Scientific Reports, 5(14340), 1-10.

Rummel, C. D., Loder, M. G. J., Fricke, N. F., Lang, T., Griebeler, E. M., Janke, M. \& Gerdts, G. (2016). Plastic Ingestion by Pelagic and Demersal Fish From the North Sea and Baltic Sea. Marine Pollution Bulletin, 102(1), 134-141.

Sarwanto, C., Eko, S. W., Tri, W. N. \& John, H. (2014). Kajian Sistem Pemasaran Ikan Hasil Tangkapan Nelayan. J. Sosek KP, 9(2), 207-217.
Susilo, H. (2010). Analisis Bioekologi Pada Pemanfaatan Sumberdaya Ikan Pelagis Besar di Perairan Bontang. EPP, 3(1), 25-30.

Vendel, A. L., Bessa, F., Alves, V. E. N., Amorim, A. L. A., Patrício, J. \& Palma, A. R. T. (2017). Widespread Microplastic Ingestion by Fish Assemblages in Tropical Estuaries Subjected to Anthropogenic Pressures. Marine Pollution Bulletin, 117(1-2), 448-455.

Wahyuni, I. S., Hartati, S. T. \& Indarsyah, I. J. (2009). Informasi Biologi Perikanan Ikan Kurisi, Nemipterus japonicus, di Blanakan dan Tegal. BAWAL, 2(4), 171176.

Widianarko, B. \& Hantoro, I. (2018). Mikroplastik dalam Seafood dari Pantai Utara Jawa. Semarang: Universitas Katolik Soegijapranata.

Wright, S. L., Thompson, R. C. \& Galloway, T. S. (2013). The Physical Impacts of Microplastics on Marine Organisms: A Review. Environmental Pollution, 178, 483-492. 